\title{
Antimicrobial activity and chemical constituents of essential oils and oleoresins extracted from eight pepper species
}

\author{
Laira Martinelli ${ }^{1}$ Jessica Miranda Rosa ${ }^{1}$ Carolina dos Santos Bragine Ferreira ${ }^{1}$ \\ Gustavo Marcelo da Luz Nascimento ${ }^{2}$ Mateus Silveira Freitas ${ }^{2}$ Luiz Carlos Pizato ${ }^{3}$ \\ Wanderson de Oliveira Santos $^{3}$ Ricardo Francisco Pires ${ }^{1,2}$ Mônica Hitomi Okura ${ }^{2}$ \\ Geoffroy Roger Pointer Malpass ${ }^{1,2}$ Ana Claudia Granato ${ }^{1,2 *}$
}

\footnotetext{
${ }^{1}$ Departamento de Engenharia Química, Instituto de Ciências Tecnológicas e Exatas, Universidade Federal do Triângulo Mineiro (UFTM), Uberaba, MG, Brasil. ${ }^{2}$ Programa de Mestrado Profissional em Inovação Tecnológica, Universidade Federal do Triângulo Mineiro (UFTM), 38064-200, Uberaba, MG, Brasil. E-mail: ana.malpass@uftm.edu.br. "Corresponding author.

${ }^{3}$ Ourofino Agrociências, Uberaba, MG, Brasil.
}

\begin{abstract}
Essential oils are the most important compounds produced during secondary metabolism in aromatic plants. Essential oils are volatile, have characteristic odor and are used as defensive agents by plants. In pepper, it is possible to say that essential oils are the "flavor fingerprint" of each species. In the present article, eight species of pepper were studied in order to extract their essential oils and oleoresins, test their antibacterial and antifungal activities and also to identify the compounds present in the most bioactive samples. Results demonstrated that two essential oils [Pimenta dioica (L.) Merr. and Schinus terebinthifolius] and three oleoresins (Schinus terebinthifolius and Piper nigrum white and black) recorded significant antimicrobial activity. These active essential oils and oleoresins are interesting for use in biotechnological processes employed in food, pharmaceutical and other industries.
\end{abstract}

Key words: peppers, essential oil, oleoresins, antimicrobial activity, GC-MS.

Atividade antimicrobiana e constituintes químicos dos óleos essenciais e oleoresinas extraídas

RESUMO: Os óleos essenciais são os compostos mais importantes produzidos durante o metabolismo secundário de plantas aromáticas. No caso das pimentas, é possível afirmar que os óleos essenciais são a "impressão digital do sabor" de cada espécie. No presente artigo, oito espécies de pimenta foram estudadas a fim de extrair seus óleos essenciais e oleoresinas, testar a sua atividade antibacteriana e antifúngica, bem como, identificar os compostos presentes nas amostras mais ativas. Os resultados obtidos mostram que dois óleos essenciais (Pimenta dioica e Schinus terebinthifolius) e três oleoresinas (Schinus terebinthifolius e Piper nigrum branco e preto) apresentaram atividade antimicrobiana significativa. Esses óleos essenciais e oleoresinas bioativos mostram-se interessantes para a utilização em processos biotecnológicos empregados na indústria alimentar, farmacêutica e outras indústrias.

Palavras-chave: pimentas, óleo essencial, oleoresinas, atividade antimicrobiana, CG-EM.

\section{INTRODUCTION}

Plants are able to biosynthesize thousands of primary and secondary metabolites with various functions and biological activities. However, only some of these compounds will generate the "flavor fingerprint" of each specie (GOFF \& KLEE, 2006). Essential oils are volatile secondary metabolites formed by aromatic plants and can generally be recognized by their characteristic odor (BAKKALI et al., 2008). Their production is known to occur throughout the plant kingdom. Many epidermal cellular structures are capable of producing essential oils and there is a wide variety of chemical constituents (SANGWAN et al., 2001).
Essential oils are projected to protect the plant by acting as antifungal, antibacterial, insecticidal or antiviral components and are also thought to promote the dispersion of seeds and pollens by attracting insects (BAKKALI et al., 2008). Essential oils are basically composed of terpenes and aromatic polypropanoid compounds derived from the acetate-mevalonic acid and the shikimic acid pathways, respectively. However, the essential oil composition can vary with the developmental stage of the plant (CHARLES \& SIMON, 1990; SANGWAN et al., 2001).

Essential oils have been used as antibacterial, antifungal, antioxidant and insecticidal agents (CHARLES \& SIMON, 
1990). BAKKALI et al. (2008) has shown that about 3000 essential oils are known and 300 are commercially important for the pharmaceutical, agronomic, food, sanitary products, cosmetic, perfume and make-up industries. Essential oils are also used in dentistry and as food preservatives and additives.

Several techniques are employed for extracting essential oils: hydro-distillation, steam distillation, solvent extraction, supercritical $\mathrm{CO}_{2}$ extraction and microwave extraction. Composition and quantity of the extracted essential oil may vary for different extraction methods (BAKKALI et al., 2008).

Hydro-distillation is the main method for obtaining essential oils. In this method, the material to undergo extraction is mixed with water and then heated. Alternatively, the material to undergo extraction is placed apart from the water and steam passes through the sample, extracting the essential oil. In both types of extraction, essential oil is obtained as an aqueous extract and must be separated. Other methods also provide extracts with similar or better quality, such as solvent extraction (VINATORU, 2001).

In one form of solvent extraction, Soxhlet extraction, the material to undergo extraction is repeatedly brought into contact with fresh portions of extractant, which facilitates displacement of the transfer equilibrium. In addition, no filtration is required after extraction and sample throughput can be increased by performing several simultaneous extractions in parallel (LUQUE de CASTRO \& PRIEGO-CAPOTE, 2010).

SUHAJ (2006), reviewed the isolation of antioxidant compounds for several spices, including peppers. SOUTO et al. (2012) reported the insecticidal activity of the essential oil of Piper aduncum, Piper marginatum, Piper divaricatum and Piper callosum against the ant Solenopsis saevissima and detected various compounds by Gas Chromatography coupled with Mass Spectrometry (GC-MS) that were previously known as having insecticidal activity. MARTINS et al. (2014), studied the essential oil of Schinus molle essential oils (the leaf and the fruits) and reported that both oils have low antioxidant activity, antimicrobial activity against Gram + and Gram - bacteria and spoilage fungi with low toxicity in vivo in mice $(2000 \mathrm{mg}$ $\mathrm{kg}^{-1}$ ). KAPOOR et al. (2009) demonstrated the antioxidant and scavenging activity of Piper nigurm essential oil and oleoresins, which have important applications in food chemistry.
This paper has the goal of extracting essential oils of some peppers widely used in Brazilian cuisine. After extraction, the antimicrobial activity of the oils was investigated and bioactive extracts were characterized by Gas Chromatography coupled with Mass Spectrometry (GC-MS). A statistical analysis of the data obtained was also performed using the software package Statistica ${ }^{\circledR}$.

\section{MATERIALS AND METHODS}

\section{Plant materials}

All the peppers were commercially acquired from local sellers in the city of Uberaba Minas Gerais, Brazil. The following peppers were studied: Schinus terebinthifolius (Anacardiaceae Family); Piper nigrum, white and black (Piperaceae Family); Pimenta dioica (Myrtaceae Family); Capsicum baccatum and Capsicum frutescents (Solanaceae Family); and two species of Capsicum chinense (Solanaceae Family). For the first three species the grains were used and for the last three the fruits without the stalk were used.

\section{Extraction}

The peppers studied were washed with neutral detergent and then copiously rinsed with distilled water and dried before extraction. Volume of material was maintained constant. Essential oils were extracted using two methods: Extraction by hydrodistillation: The sample was placed in $500 \mathrm{~mL}$ round-bottomed flask with distilled water and the essential oil was extracted by water distillation using a Clevenger apparatus. After the distillation period, a partition with dichloromethane was performed (3 $\mathrm{x} 30 \mathrm{~mL}$ ) to separate the oil from the water. The oil was concentrated in a rotary evaporator to eliminate the dichloromethane. Soxhlet extraction: The sample was added to a cartridge that was capped with cotton. The cartridge was placed in a Soxhlet extractor, which was embedded in an acetonecontaining $500 \mathrm{~mL}$ round-bottomed flask, which was attached to a heating mantle. After the extraction period, the solvent was evaporated in a rotary evaporator (TECNAL, TE-210) and the oleoresin was obtained.

\section{Antimicrobial activity}

Microorganisms evaluated in this study were Gram-negative bacteria: Escherichia coli (ATCC 35218), Gram-positive bacteria: Staphylococcus aureus (ATCC 29213) and Bacillus cereus (ATCC 11778), Fungi: Candida albicans 
(ATCC 10231) Aspergillus niger (acquired from the environment) and Penicillium sp (acquired from the environment of the laboratory).

Antimicrobial activity and minimum inhibitory concentration (MIC) of the essential oils and oleoresins were tested against the fungi and bacteria studied according to the broth dilution method in microplate (a BHI culture medium for fungi and Mueller-Hinton broth for bacteria) (NCCLS, 1992; NCCLS, 2003). Dilutions from $1-0.05 \%$ of the samples (essential oils and oleoresins) were prepared in order to determine the MIC. In addition, positive controls for each fungus and each bacteria and negative controls, containing only the culture medium were used. After $72 \mathrm{~h}$ growth at $28^{\circ} \mathrm{C}$ for the fungi and $24 \mathrm{~h}$ at $37^{\circ} \mathrm{C}$ for bacteria, each well of the microplate was observed individually. If the sample presented turbidity, it was considered inactive.

\section{$G C-M S$ analysis}

For the GC-MS analysis of the essential oils, the samples were diluted in methanol at a concentration of $1 \mu \mathrm{L} / \mathrm{ml}$. Analyses were performed using a Shimadzu GC-MS 2010 apparatus coupled to a quadrupole detector, with a VF-5MS column $(30 \mathrm{~m} \times 0.25 \mathrm{~mm}$ with $0: 25 \mathrm{~mm}$ of film thickness). $1 \mu \mathrm{L}$ of each oil was injected separately at a ratio of 1:20 in Split mode, the injector temperature was $250^{\circ} \mathrm{C}$ and ionization energy at $70 \mathrm{eV}$. Oven temperature was started at $50^{\circ} \mathrm{C}$ and was set to $250^{\circ} \mathrm{C}$ at a rate of $3^{\circ} \mathrm{C} \mathrm{min}^{-1}$ and then kept constant for $10 \mathrm{~min}$. Identification of compounds was based on comparison of their mass spectra and their retention indices related with the National Institute of Standards and Technology Library.

\section{Statistical analysis}

A statistical analysis was performed to verify the independent variables of the pepper and the extraction method on the extraction yield. Thus, a factorial variance analysis table (ANOVA) was obtained. In this analysis it was possible to verify effects of types of pepper, extraction methodology and interaction between the method and pepper variables on the dependent variable: the extraction yield. For this statistical analysis, the software STATISTICA ${ }^{\circledR}$ was employed (STATSOFT, 2004).

\section{RESULTS AND DISCUSSION}

\section{Extractions}

Extraction data (using Soxhlet and Clevenger apparatus) are shown in table 1. The extraction from grain peppers (P. nigrum - white and black - and $S$. terebinthifolius) generated a much lower volume of both oleoresins (Soxhlet) and essential oils (Clevenger) compared to red peppers (C. baccatum, $C$. chinense $1, C$. chinense 2 and $C$. frutenscens). These results were expected as it is known that the amount of essential oil in grain pepper is very low. However, the percentage yield of essential oil or oleoresin obtained for the study of grain pepper was considered satisfactory.

\section{Antimicrobial activity}

The MIC of the essential oils and oleoresins against bacteria and the fungi studied are given in table 2 . The best results for the oleoresins for the bacteria studied were $P$. nigrum (white) and S. terebinthifolius for B. cereus $(0.10 \%$ both), S. terebinthifolius for E. coli $(0.10 \%)$ and C. frutescens and P. dioica for S. aureus $(0.25 \%$ both). However, C. frutescens and $P$. dioica $(0.10 \%$ both) gave the best results for $A$. niger. Interesting is the fact that for the essential oils only $P$. dioica and $S$. terebinthifolius expressed significant results ( $0.10 \%$ both) for $B$. cereus. Taking into account the fungi, the oleoresins of $C$. frutescens and $P$. dioica demontrated the best results and only for $A$. niger $(0.10 \%$ both $)$, which can be considered a certain selectivity of theses extracts. So, possibly oleoresins are more active because the solvent extraction and the repeated extraction obtained from the Soxhlet method leads to an extract in which the amount of active compound is greater when compared to the essential oil

\section{GC-MS analysis}

As the oleoresins of both $P$. nigrum (black and white), the oleoresin and the essential oil of $S$. terebinthifolius and only the essential oil of $P$. dioica reported significant activity against the bacteria and the fungi evaluated, the GC-MS analysis was limited to these samples. Compounds detected by GC-MS for these essential oils/oleoresins are summarized in table 2.

According to the GC-MS analyses of the essential oil and the oleoresin of $S$. terebinthifolius both are completely different. In the essential oil seven compounds were encountered: $\alpha$-pinene, $\alpha$-phellandrene, $\beta$-pinene, $\beta$-mircene, trans3-caren-2-ol, o-cimene and (-)-limonene. Conversely, in the oleoresin only four compounds were identified: camphene, $\alpha$-Terpineol, geraniol and $\delta$-copaene. Components of the essential oil and the oleoresin of $S$. terebinthifolius are not 
Table 1 - Extractions data for the studied peppers. Extraction time: $120 \mathrm{~min}$.

\begin{tabular}{|c|c|c|c|c|c|c|}
\hline \multirow[b]{2}{*}{ Peppers } & \multicolumn{3}{|c|}{ 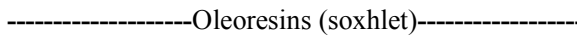 } & \multicolumn{3}{|c|}{---------Essential oils (clevenger)---------' } \\
\hline & Pepper mass (g) & 71.43 & 71.15 & 112.33 & 7.72 & 6.90 \\
\hline C baccatum & 100.39 & & & & & \\
\hline C. chinense 1 & 47.90 & 13.90 & 29.02 & 39.38 & 7.44 & 18.90 \\
\hline C. chinense 2 & 75.51 & 48.48 & 64.20 & 40.12 & 0.61 & 1.52 \\
\hline$C$ frutenscens & 80.05 & 40.10 & 50.10 & 81.28 & 8.69 & 10.70 \\
\hline P. dioica & 35.96 & 2.49 & 6.92 & 37.28 & 1.02 & 2.74 \\
\hline P. nigrum (black) & 60.20 & 4.91 & 8.16 & 40.21 & 0.75 & 1.90 \\
\hline P. nigrum (white) & 30.14 & 3.60 & 11.95 & 40.12 & 0.60 & 1.50 \\
\hline S.terebinthifolius & 30.06 & 4.11 & 13.70 & 36.09 & 0.61 & 1.70 \\
\hline
\end{tabular}

the same, which was expected as the extraction methods used can lead to different kind of extracts. Both results are in agreement with MARTINS et al. (2014).
For the essential oil of $P$. dioica, eight compounds were found: $\beta$-myrcene, $\alpha$-phellandrene, 1 -pentanone, (-)-limonene, $\beta$-pinene, $\gamma$-terpineno, p-eugenol and biciclo [7,2,0]-undec-4-eno-4,11,11-

Table 2 - MIC and GC-MS data of the essential oils and oleoresins studied.

\begin{tabular}{|c|c|c|c|c|c|c|}
\hline & B. cereus & E. coli & S. aureus & A. niger & C. albicans & Penicilium sp. \\
\hline C. baccatum & $0.25 \%$ & - & - & - & - & - \\
\hline C. chinense 1 & $1.00 \%$ & - & - & - & - & - \\
\hline C. chinense 2 & $0.25 \%$ & - & - & - & - & $1.00 \%$ \\
\hline C. frutescens & $0.25 \%$ & $0.50 \%$ & $0.25 \%$ & $0.10 \%$ & $0.50 \%$ & $0.25 \%$ \\
\hline P. dioica & $0.25 \%$ & $0.50 \%$ & $0.25 \%$ & $0.10 \%$ & $0.50 \%$ & $0.25 \%$ \\
\hline P. nigrum (black) & $1.00 \%$ & - & - & - & - & - \\
\hline P. nigrum (white) & $0.10 \%$ & - & - & - & $0.50 \%$ & - \\
\hline S. terebinthifolius & $0.10 \%$ & $0.10 \%$ & $0.25 \%$ & - & $0.25 \%$ & $0.25 \%$ \\
\hline \multicolumn{7}{|l|}{-----------------------. } \\
\hline & B. cereus & E. coli & S. aureus & A. niger & C. albicans & Penicilium sp. \\
\hline C. baccatum & $0.25 \%$ & - & - & - & - & - \\
\hline C. chinense 1 & $0.25 \%$ & - & - & - & - & - \\
\hline C. chinense 2 & $0.25 \%$ & - & - & - & - & $1.00 \%$ \\
\hline C. frutescens & $0.50 \%$ & - & - & - & - & - \\
\hline P. dioica & $0.10 \%$ & $0.50 \%$ & $1.00 \%$ & $0.25 \%$ & $0.25 \%$ & $0.25 \%$ \\
\hline P. nigrum (black) & $0.25 \%$ & - & $1.00 \%$ & - & $0.50 \%$ & - \\
\hline P. nigrum (white) & $0.25 \%$ & $1.00 \%$ & $0.50 \%$ & - & - & - \\
\hline S. terebinthifolius & $0.10 \%$ & $0.25 \%$ & $0.50 \%$ & - & $0.25 \%$ & $0.25 \%$ \\
\hline \multicolumn{7}{|c|}{ 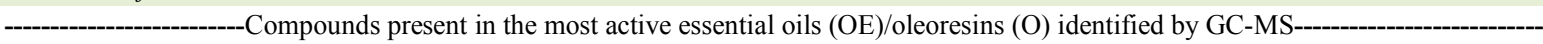 } \\
\hline O S. terebinthifolius & EO S. terebinthifolius & \multicolumn{2}{|c|}{ EO $P$. dioica } & O P. nigrum & \multicolumn{2}{|c|}{ O P. nigrum (white) } \\
\hline Name (RT) & Name (RT) & \multicolumn{2}{|c|}{ Name (RT) } & Name $(\mathrm{H}$ & \multicolumn{2}{|c|}{ Name (RT) } \\
\hline Camphene (9.23) & $\alpha$-pinene (7.12) & \multicolumn{2}{|c|}{$\beta$-myrcene (9.09) } & Sabinene & \multicolumn{2}{|c|}{ Camphene (9.25) } \\
\hline$\alpha$-Terpineol (11.90) & $\alpha$-phellandrene (8.48) & \multicolumn{2}{|c|}{$\alpha$-phellandrene (9.74) } & $\begin{array}{r}\text { trans-sabinen } \\
(11.07\end{array}$ & \multicolumn{2}{|c|}{$\begin{array}{c}\text { trans-sabinene hydrate } \\
(11.08)\end{array}$} \\
\hline Geraniol (12.67) & $\beta$-pinene (8.66) & \multicolumn{2}{|c|}{ 2-pentanone (10.46) } & $\alpha$-copaene & \multicolumn{2}{|c|}{$\alpha$-copaene (13.75) } \\
\hline$\delta$-copaene (13.74) & $\beta$-myrcene (9.09) & \multicolumn{2}{|c|}{ (-)-limonene (10.65) } & & & \\
\hline & Trans-3-caren-2-ol (9.74) & $\beta-p$ & 13.67) & & & \\
\hline & $1 R$ - $\alpha$-pinene $(9.83)$ & $\gamma$-ter & (17.24) & & & \\
\hline & o-cymene (10.46) & $\mathrm{p}-\mathrm{el}$ & 24.89) & & & \\
\hline & (-)-limonene (10.66) & & & & & \\
\hline
\end{tabular}

Ciência Rural, v.47, n.5, 2017. 
trimethyl-8-metilene. According to Rao et al. the major compounds detected in the essential oil from the fruits of $P$. dioica were: limonene, 1,8-cineole, terpinolene, $\beta$-cariofillene, $\beta$-selinene and methyl eugenol. However, the compounds reported in the essential oil from the leaves of $P$. dioica were: eugenol, methyl eugenol, $\beta$-cariofillene and myrcene (RAO et al., 2012).

The GC-MS analysis of the oleoresin of both $P$. nigrum (black and white) identified three compounds, trans-sabinene hydrate and $\alpha$-copaene. However, sabinene was identified in the oleoresin of $P$. nigrum (black) and Camphene were reported in $P$. nigrum (white). These compounds were also reported by Kapoor et al. (2009) studying the same species.

The slight differences observed compared to the literature can probably be described to the local conditions. The variation in the chemical composition of the oleoresin/essential oil from the plants studied is a direct relationship with the environment in which the plant grows the type of soil, the seasonality and also the part of the plant extracted (MARTINS, et al., 2014).

GOFF \& KLEE (2006) have proposed that spices can be used to improve food preservation. In DIAZ et al. (2008) the essential oil of the leaf of Schinus molle was constituted mainly by the monoterpenoids $\alpha$ - and $\beta$-pinene. The essential oil studied showed citotoxity against Breast carcinoma cell line and also against Leukemic cell line K562 (DIAZ et al., 2008). Capsaicin is the predominant compound in pungent peppers of Capsicun genera and is known to induce depletion of substance $\mathrm{P}$ and other neuropeptides from sensory nerve terminals (PALEVITCH \& CRAKER, 1995).

From the results obtained in this study is possible to claim that the essential oil of $P$. dioica and $S$. terebinthifolius, as well as the three oleoresins of $S$. terebinthifolius and $P$. nigrum (white and black), have important antimicrobial properties for use in the food, pharmaceutical and cosmetics industries and also in other biotechnological processes.

\section{Statistical analysis}

A displays, in summary, the results of the ANOVA test, presenting the square sums, degrees of freedom, mean square variance and the statistical p. According to figure $1 \mathrm{~A}$, considering a significance level of $5 \%(\mathrm{P}=0.05)$, it is observed that for the pepper variable $\mathrm{P}<0.05$ within the $\mathrm{H} 0$ rejection region. Therefore, types of peppers are a statistically different variable, i.e., this variable influences the efficiency of extraction. Continuing with figure $1 \mathrm{~A}$, it is noted that the variable type of extraction method influences the response variable ( $\mathrm{P}<0.05$, within $\mathrm{H} 0$, the rejection region), both are statistically different methodologies. Considering the effect of interaction between the variables pepper and extraction methodology, it is observed in figure $1 \mathrm{~A}$ that the value of $\mathrm{P}<0.05$ (also within the $\mathrm{H} 0$ rejection region) denotes that the interaction between these variables has an interference response. Figure 1B presents the values predicted by the model and those observed experimentally. It can be observed that the model adequately describes the experimental results.

According to the ANOVA (Figure 1A), the yield is a function of the type of extraction methodology, type of pepper andinteraction between types of extraction, as these were the statistically important variables. This can be proven by the low $\mathrm{P}$ values obtained for these effects. Figure 1C also shows the yield when comparing the extraction methodologies. This suggests that the Sohxlet method has a higher yield than the Clevenger methodology for the three types of peppers employed. Figure 1D presents the yields depending on the type of pepper employed and demonstrated that the highest yields were obtained for extractions in which S. terebinthifolius was studied. Moreover, it is suspected that, statistically, the $P$. dioica and $P$. nigrum (white and black) have similar effects on the yield. In Figure $1 \mathrm{E}$ the yields due to the interaction between the extraction methods and type of pepper employed are given. Sohxlet methodology associated with $S$. terebinthifolius pepper corresponds to the higher yield.

\section{CONCLUSION}

From the eight types of peppers studied, two essential oils ( $P$. dioica and $S$. terebinthifolius) and three oleoresins ( $S$. terebinthifolius and $P$. nigrum white and black) presented significant antimicrobial activity. The GC-MS analysis revealed the presence of compounds previously detected by other authors. From the statistical analysis, it was concluded that the Soxhlet method and S. terebinthifolius led to the highest yield. The active oils and oleoresins are interesting for use in biotechnological processes employed in the food, pharmaceutical and other industries. 


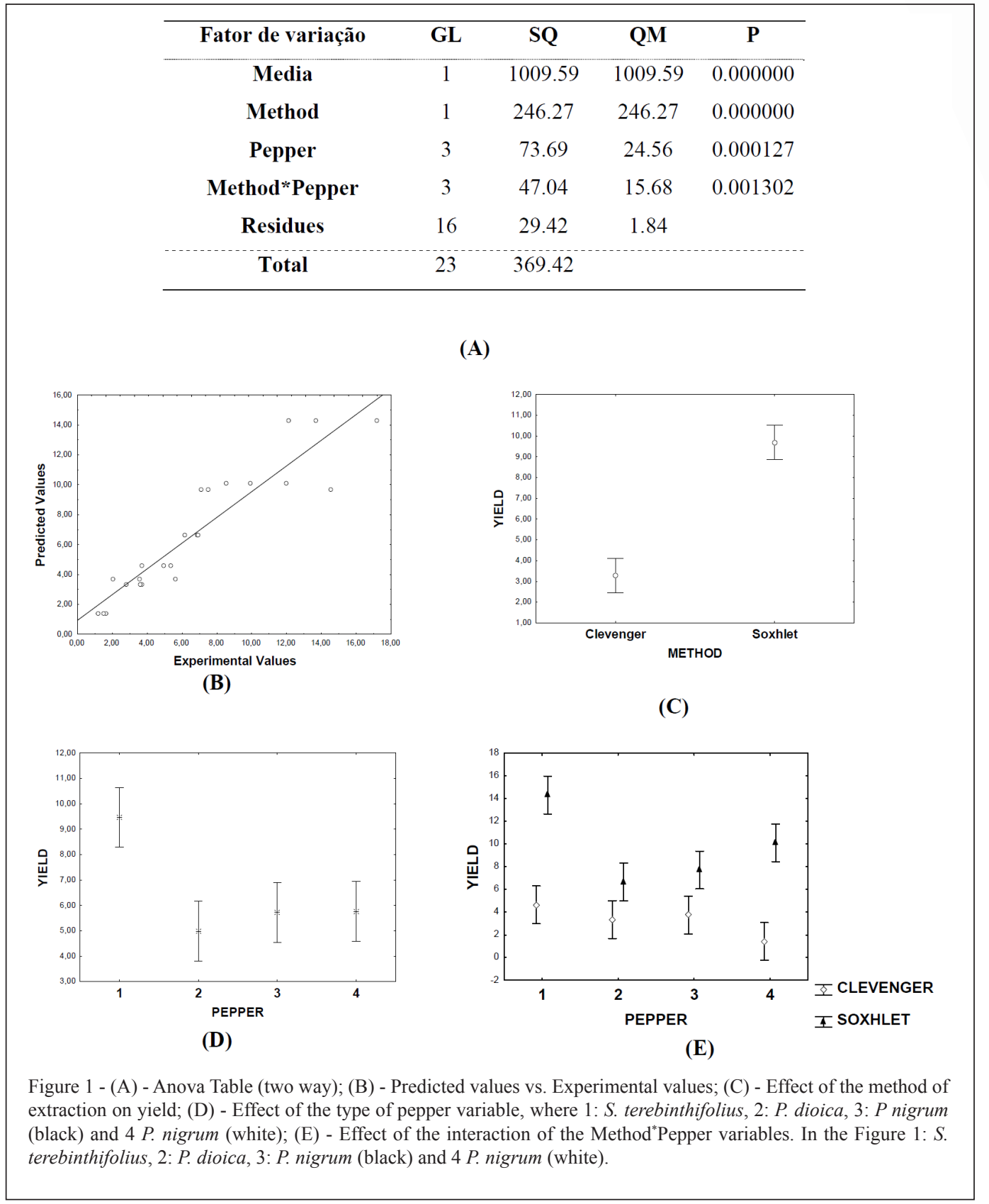

\section{ACKNOWLEDGEMENTS}

The authors acknowledge the financial support of Fundação de Amparo a Pesquisa de Minas Gerais (FAPEMIG) (APQ-01572-14, APQ-01833-12, MPR-00265-15) and Conselho Nacional de Desenvolvimento Científico e Tecnológico (CNPq) $(475730 / 2012-7 ; 303892 / 2015-3 ; 441614 / 2014-0)$. This work is a collaboration research project of members of the Rede Mineira de Química (RQ-MG) supported by Fundação de Amparo a Pesquisa de Minas Gerais (FAPEMIG) (Project: CEX - RED-00010-14).

\section{REFERENCES}

BAKKALI, F. et al. Biological effects of essential oils - A review. Food and Chemical Toxicology, v.46, p.446-475, 2008. Available from: <http://www.sciencedirect.com/science/article/pii/ S0278691507004541>. Accessed: Sept. 20, 2016. doi: 10.1016/j. fct.2007.09.106.

CHARLES, D.J.; SIMON. J. E. Comparison of extraction methods for the rapid determination of essential oil content and composition of Basil. 
Journal of the American Society for Horticultural Science, v.115, p.458-462, 1990. Available from: <http://journal.ashspublications.org/ content/115/3/458.abstract>. Accessed: Sept. 20, 2016.

DIAZ, C. et al. Chemical composition of Schinus molle essential oil and its cytotoxic activity on tumour cell lines. Natural Product Research, v.22, p.1521-1534, 2008. Available from: <http:// www.tandfonline.com/doi/abs/10.1080/14786410701848154>. Accessed: Sept. 20, 2016. doi: 10.1080/14786410701848154.

GOFF, S. A.; KLEE, H. J. Plant volatile compounds: sensory cues for health and nutritional value? Science, v.311, p.815-819, 2006. Available from: <http://science.sciencemag.org/content/311/5762/815>. Accessed: Sept. 20, 2016. doi: 10.1126/science.1112614.

KAPOOR, I. P. S. Chemistry and in vitro antioxidant activity of volatile oil and oleoresins of black pepper (Piper nigrum). Journal of Agricultural and Food Chemistry, v.57, p.5358-5364, 2009. Available from: <http://pubs.acs.org/doi/abs/10.1021/jf900642x $>$. Accessed: Sept. 23, 2016. doi: 10.1021/jf900642x.

LUQUE de CASTRO, M. D.; PRIEGO-CAPOTE, F. Soxhlet extraction: past and present panacea. Journal of Chromatography A, v.1217, p.2283-2289, 2010. Available from: <http://www. sciencedirect.com/science/article/pii/S0021967309016884>. Accessed: Sept. 23, 2016. doi: 10.1016/j.chroma.2009.11.027.

MARTINS, M. R. et al. Antioxidant, antimicrobial and toxicological properties of Schinus molle L. essential oils. Journal of Ethnopharmacology, v.151,p.485-492,2014. Available from: $<$ http:// www.sciencedirect.com/science/article/pii/S0378874113007897>. Accessed: Sept. 23, 2016. doi: 10.1016/j.jep.2013.10.063.

NCCLS (NATIONAL COMMITTEE FOR CLINICAL LABORATORY STANDARDS). Reference method for broth dilution antifungal susceptibility testing of yeasts; proposed standard NCCLS. Wayne: National Committee for Clinical Laboratory Standards, 1992. Document M27-P.

NCCLS (NATIONAL COMMITTEE FOR CLINICAL LABORATORY STANDARDS). Metodologia dos testes de sensibilidade a agentes antimicrobianos por diluição para bactéria de crescimento aeróbico. 6.ed. West Valley Road, Pennsylvania, USA, 2003. V.23, n.2. (Norma M7-A6).

PALEVITCH, D.; CRAKER, L. E. Nutritional and medical importance of red pepper (Capsicum spp.). Journal of Herbs, Spices \& Medicinal Plants, v.3, p.55-83, 1995. Available from: $<$ http://www.tandfonline.com/doi/abs/10.1300/J044v03n02_08>. Accessed: Sept. 23, 2016. doi: 10.1300/J044v03n02_08.

RAO, P. S. et al. An important spice, Pimenta dioica (Linn.) Merill: a review. International Current Pharmaceutical Journal, v.1, p.221-225, 2012. Available from: $<$ http://www. banglajol.info/index.php/ICPJ/article/view/11255/8225>. Accessed: Sept. 23, 2016.

SANGWAN, N. S. et al. Regulation of essential oil production in plants. Plant Growth Regulation, v.34, p.3-21, 2001. Available from:<http://link.springer.com/article/10.1023/A:1013386921596>. Accessed: Sept. 23, 2016. doi: 10.1023/A:1013386921596.

\section{STATSOFT, INC. Software Statistica 7.0. USA, 2004.}

SOUTO, R. N. P. et al. Insecticidal activity of piper essential oils from the Amazon againstthe fire ant Solenopsis saevissima (Smith) (Hymenoptera: Formicidae). Neotropical Entomology, v.41, p.510-517, 2012. Available from: <http://link.springer.com/ article/10.1007/s13744-012-0080-6>. Accessed: Nov. 24, 2016. doi: $10.1007 / \mathrm{s} 13744-012-0080-6$.

SUHAJ, M. Spice antioxidants isolation and their antiradical activity: a review. Journal of Food Composition and Analysis, v.19, p.531-537, 2006. Available from: <http://www.sciencedirect. com/science/article/pii/S0889157505000232> . Accessed: Nov. 24, 2016. doi: 10.1016/j.jfca.2004.11.005.

VINATORU, M. An overview of the ultrasonically assisted extraction of bioactive principles from herbs. Ultrasonics Sonochemistry, v.8, p.303-313, 2001. Available from: <http:// www.sciencedirect.com/science/article/pii/S1350417701000712>. Accessed: Sept. 23, 2016. doi: 10.1016/S1350-4177(01)00071-2. 